\title{
Хронічний панкреатит та цукровий діабет - предиктори розвитку раку підшлункової залози
}

\author{
А. І. Суходоля ${ }^{1,2}$, С. А. Суходоля ${ }^{2}$ В. П. Мосійчук ${ }^{1,2}$, М. В. Макогонський ${ }^{1,2}$ \\ ${ }^{1}$ Вінницький національний медичний університет імені М. І. Пирогова, \\ ${ }^{2}$ Хмельницька обласна лікарня
}

\section{Chronic pancreatitis and diabetes mellitus - predictors of development of pancreatic cancer}

\author{
A. I. Sukhodolia ${ }^{1,2}$, S. A. Sukhodolia' ${ }^{2}$, V. P. Mosiychuk ${ }^{1,2}$, M. V. Makohonskyi ${ }^{1,2}$ \\ ${ }^{1}$ Pyrogov National Medical University, Vinnytsya, \\ ${ }^{2}$ Khmelnytskyi Regional Hospital
}

\begin{abstract}
Хронічний панкреатит (ХП) - це прогресуюче запально-дегенеративне, поліетіологічне захворювання з різноманітними проявами. Маніфестні або стерті епізоди гострого панкреатиту (ГП) призводять до дискординованої передчасної активації ацинарних ензимів, яка спричиняє прогресуюче пошкодження підшлункової залози (ПЗ). Екзокринна тканина є основною складовою ПЗ, у яку вбудований ендокринний компонент. Екзокринні ацинарні клітини, яким притаманна секреторна функція, продукують гідролітичні травні ферменти, тоді як протоки, які секретують муцини, формують розгалужену транспортну мережу для потрапляння секрету ПЗ до кишечника. Пошкодження екзокринної та ендокринної тканини призводить до тяжкої мальдигестії та цукрового діабету (ЦД).

Гістопатологічними особливостями ХП є ацинарна атрофія, фіброз, жирова трансформація, хронічне запалення та розвиток аномальних проток. Окрім загальноприйнятих клінічних симптомів, таких як біль, екзокринна недостатність та ЦД, ХП може загрожувати підвищеним ризиком розвитку раку підшлункової залози (РПЗ) [1, 2]. Протокова аденокарцинома є найбільш частим неопластичним ураженням ПЗ [3].

Численними експериментальними дослідженнями виявлено взаємозв'язок між формуванням протокового метапластичного епітелію та змінами в ацинарних клітинах П3, тим самим підтверджено взаємозв'язок між ХП та РПЗ [4]. Ідея ацинарноклітинного походження РПЗ сформувалась ще у 90-ті роки минулого століття [5]. Взаємозв'язок між ХП та РПЗ став об'єктом численних досліджень, у більшості яких доведено значну спорідненість цих двох захворювань [6]. Однак деталі цього взаємозв'язку, патогенез, фактори ризику та можливості диференціації залишаються не до кінця вивченими. Саме тому досить часто оперативні втручання з приводу ХП виконують не у повному об'ємі, що не убезпечує від подальшого прогресування хвороби.

У цьому огляді проаналізовані знайдені в доступній літературі дані про зв'язок ХП, ЦД та РПЗ, напрямки розвитку та можливі шляхи вирішення існуючої проблеми.
\end{abstract}

На сьогодні РПЗ вважають одним із найнебезпечніших типів раку серед більш ніж 60 різновидів злоякісних новоутворень [7]. За оцінкою GLOBOCAN 2012, РПЗ спричиняє понад 331000 смертей на рік в усьому світі та стоїть на сьомому місці у структурі смертей, спричинених раком. У 2012 р. в усьому світі 338000 людей мали підтверджений діагноз РПЗ [8].

За результатами останнього дослідження GLOBOCAN 2018, проведеного Міжнародною агенцією досліджень раку, кількість хворих з діагностованим РПЗ зросла до 458 918, а кількість смертей, спричинених РП3, - до 432242 [9]. На думку Т. Muniraj і співавторів, до 2020 р. РПЗ займе друге місце у структурі смертей, пов'язаних зі злоякісними новоутвореннями [10]. В Україні у 2012 р. зареєстровано 4728 чоловіків і жінок з РПЗ та 4168 смертей, спричинених ускладненнями РПЗ. Зазначене підтверджує прогресування даної патології та актуальність проблеми діагностики РПЗ та боротьби з ним.

На нашу думку, кількість хворих є дещо більшою, оскільки через стерту клінічну картину хворі рідко звертаються за допомогою. Слід також враховувати, що значній кількості тяжкохворих, померлих у стаціонарі, не виконують секційного дослідження. Показник 5-річної виживаності після радикальних оперативних втручань $є$ порівнянним із світовими показниками і становить 5 - 6\% [3, 11].

В. Копчак і співавтори, проаналізувавши досвід виконання 468 панкреатодуоденальних резекцій з 1998 по 2010 р., дійшли висновку, що найбільш адекватним етапом хірургічного лікування злоякісних періампулярних пухлин слід вважати панкреатодуоденальну резекцію з модифікованою розширеною радикальною лімфаденектомією [12].

РПЗ має невтішний прогноз та негативну динаміку насамперед через пізню діагностику, оскільки у понад 90\% хворих РПЗ діагностують на III та IV стадіях, що не дає можливості виконати радикальне оперативне втручання [13]. За даними дослідження А. Кanno і співавторів серед 6942 пацієнтів лише у 200 (3\%) були стадія 0 та стадія $1(\mathrm{a}+\mathrm{b})$ і лише $25 \%$ із них мали хоча б якісь скарги з боку травного каналу 
[14]. Саме тому діагностувати у пацієнтів стадію 0 та стадію 1 РПЗ є досить складним та ретельним завданням. Автори визначають як ранні стадію 0 (високодиференційована панкреатична інтраепітеліальна неоплазія - PanIN/carcinoma in situ) та стадію 1 (інвазивна карцинома з діаметром пухлини до 20 мм) без метастазів у лімфатичні вузли (NO) та віддалених метастазів (M0). У свою чергу спостереження щодо стадії 1 класифікували як TS1a (пухлина розміром до 10 мм) та TS1в (пухлина розміром 11 - 20 мм) у найбільшому іï вимірі. У 83\% пацієнтів із діагностованим РПЗ стадії 0 під час ендоскопічної ретроградної холангіопанкреатографії (ЕРХПГ) діагностували дилатацію головної протоки ПЗ, пов'язану з попереднім фіброзом та можливою протоковою гіпертензією. Локальні жирові зміни виявили у 21 (42\%) із 50 пацієнтів із РПЗ стадії 0 та у 61 (41,8\%) із 146 пацієнтів з РПЗ стадії 1. Проте механізм розвитку жирових змін достеменно не відомий.

Вважають, що до розвитку РПЗ призводять попередні специфічні передракові зміни. За даними клінічних і гістопатологічних досліджень визначено три основні форми панкреатичної неоплазіі: PanIN, муцинозна кістозна неоплазія (MCN), внутрішньопротокова папілярна муцинозна неоплазія (IPMN). Найбільш поширеною та вивченою є PanIN, яку виявляють у дрібних панкреатичних протоках. Морфологічні зміни, які позначають терміном PanIN, включають у себе дезорганізацію архітектоніки циліндричного, муцинозного епітелію з ядерною атипією та мають градацію від I до III стадії. PanIN-I та PanIN-II не мають будьяких симптомів та невидимі на поперечних зрізах візуальних методів діагностики. PanIN-III, яку часто позначають як панкреатичну внутрішньопротокову карциному або карциномy in situ, має найвищий ступінь дисплазії. Ядра цих клітин збільшені, плейоморфні, хибно орієнтовані. Дані зміни найчастіше виявляють у пацієнтів з РПЗ [3, 15].

Від моменту виникнення ХП до розвитку РПЗ проходить від 10 до 20 років, хоча частота ракової трансформації становить лише 0,1 - 5\% [16]. Ймовірність виявлення РПЗ у хворих з ХП збільшується з роками - 1,1, 1,8 та 4,0\% відповідно у 5, 10- та 20-річний період спостереження [17].

Загальновідомими факторами ризику розвитку РПЗ є сімейний анамнез РПЗ, ХП та ГП, ЦД, ожиріння, кісти ПЗ, куріння, зловживання алкоголем, PanIN. Але, незважаючи на це, ефективної стратегії з урахуванням вказаних ризиків для діагностики ранньої стадії РПЗ досі не впроваджено.

Ми проаналізували результати обстеження 313 пацієнтів з приводу злоякісних утворень ПЗ, яким проводили лікування на базі Хмельницької обласної лікарні протягом останніх 6 років. Чоловіків було 178, жінок - 135. Середній вік хворих становив 65 років ( $\sigma=11,5$ року). Діагностичний скринінг включав проведення мультиспіральної комп'ютерної томографії (МСКТ), ультразвукового дослідження органів черевної порожнини (УЗД ОЧП), фіброгастроезофагодуоденоскопії (ФЕГДС), загальні та біохімічні аналізи крові, визначення рівня маркера СА 19-9. Із 313 пацієнтів 226 (72,20\%) звернулися за допомогою, маючи занедбаний стан, ускладнення хвороби та ії клінічні прояви: жовтяницю, втрату маси тіла, стеноз виходу із шлунка. Цим пацієнтам виконані паліативні оперативні втручання для усунення ускладнень та тимчасового покращення якості життя. Тільки у 14 (4,47\%) із 313 пацієнтів захворювання діагностували на ранній стадії - 1(a+b) здебільшого як знахідку під час оперативних втручань 3 приводу іншої патології. Стадії 2А та 2В діагностували у 73 (23,32\%) хворих із РПЗ. Їм виконали радикальне оперативне втручання. Віддалені результати лікування оцінені як позитивні.

Для ранньої діагностики РПЗ пацієнти, які мають фактори ризику, повинні перебувати під інтенсивним спостереженням та контролем. Слід пам'ятати про діагностичну обмеженість інструментальних методів та неможливість виконання всього спектру досліджень на доопераційному етапі. Вважаємо необхідним інтраопераційне виконання пункційної панкреатовірсунгографії для візуалізації протокової гіпертензії [18].

Ще в XIX ст. німецький патолог R. Virchow відмітив, що хронічний запальний процес призводить до злоякісного переродження клітин. Підвищену інтенсивність поділу клітин розглядають як провісник розвитку раку в багатьох органах [19]. У даному разі перебіг регенеративних процесів відбувається в умовах хронічного запального процесу [20].

В основі патогенезу ХП лежить поєднання деструкції ацинарного апарату з прогресуючим хронічним запальним процесом, що призводить до атрофії, фіброзу та гіпертензії в протоковій системі ПЗ, переважно за рахунок розвитку стриктур, мікро- та макролітіазу. Фіброз, якого зазнають уражені хронічним запаленням ділянки ПЗ, відіграє центральну роль в еволюції протокової гіпертензії, обмежуючи здатність залози розширюватись протягом періодів екзокринної секреції та поглинання тиску, створеного за рахунок збільшеного об'єму протоки [21]. Таким чином, патоморфологічні зміни у хворих з ХП характеризуються поєднанням склеротичних, атрофічних та регенеративних процесів. Спостерігаючи за 110 пацієнтами з РП3, С. J. Whatcott і співавтори виявили схожу патоморфологічну картину високий ступінь фіброзу як у первинній пухлині, так і в метастазах [22]. У численних публікаціях містяться дані про те, що хронічній запальний процес, який характеризує ХП, сприяе метаплазії та неопластичні трансформації П3 [23, 24].

Окислювальний стрес та утворення активних форм кисню (АФК) і азоту (АФА) відіграють ключову роль у патофізіології ГП та ХП зі збереженням некрозу ацинарних клітин та фіброзу. АФК/АФА сприяють модифікації нуклеїнових кислот, ліпідів та протеїнів, що призводить до фрагментації дезоксирибонуклеїнової кислоти, дезінтеграції клітинних мембран, дисфолдингу білків. Це, звичайно, активує імунну систему, яка реагує виділенням значної кількості цитокінів, хемокінів. Разом із АФК/АФА вони збільшують пошкодження епітеліальних клітин та клітинну проліферацію [25 - 27].

Одну із ключових ролей у запальному процесі та неконтрольованому рості клітин відводять ензимам циклооксигенази (ЦОГ), а саме ЦОГ-2. Встановлено, що ЦОГ-2 сприяє утворенню простагландинів, що призводить до індукції клітинного росту, а підвищений рівень ЦОГ-2 виявляють за наявності багатьох видів злоякісних новоутворень, включаючи РПЗ. Більш того, як показали імуногістохімічні дослідження, у 47 - 66\% хворих ракові клітини ПЗ гіперсекретують ЦОГ-2 [26, 28].

Активація онкогенів може відбуватись різними шляхами, включаючи точкові мутації та ампліфікацію. Ряд дослідників у 80 - 90\% хворих з РПЗ виявляли точкові мутації кодонів 12, 13 і 61 у гені $\operatorname{Kras}[29,30]$. Точкові мутації онкогена Kras призводять до утворення активної форми ras-білка, який, зв'язуючись з нуклеотидом гуанозинтрифосфатом 
(ГТФ) утворює ГТФазу, що є компонентом багатьох шляхів передачі сигналів. Формується каскад неконтрольованих внутрішньоклітинних сигналів стимуляції, що у свою чергу сприяе неконтрольованому росту клітин. Тому мутації онкогена Kras відіграють значну роль в ініціації та прогресуванні РП3, що є важливим молекулярним механізмом [31].

Відповідно до даних літератури [31, 32] загальна частота мутації гена Kras у хворих з ХП становить близько 13\%, а у хворих з РПЗ - 80 - 90\%, що значно більше, ніж за наявності інших форм раку. У 2018 р. X.Wang і співавтори, використавши новітню технологію магнітної нанопроби, опублікували нові дані про частоту мутації Kras: 81,8\% - у хворих з РПЗ та 18,5\% - у хворих з ХП [33].

Встановлено, що приблизно 95\% паціентів з РПЗ мають інактивований ген р16, через що він неспроможний пригнічувати активність цикліну $\mathrm{D}$, який значно впливає на ріст ракових клітин. В експериментальних дослідженнях продемонстровано, що трансфекція незміненого гена р16 приводить до зниження проліферації ракових клітин in vitro та in vivo [34].

Досить актуальним нині є питання кореляції ЦД та малігнізації ПЗ. Більшістю досліджень підтверджено, що близько 80\% хворих з РПЗ мали порушення толерантності до глюкози або хворіли на Цд. Крім цього, більше ніж у 85\% пацієнтів Цд виявляли за 2 роки до встановлення діагнозу РПЗ. Хворі, у яких діагностували Цд, протягом першого року мають ризик виникнення РПЗ у 16 разів більший, ніж здорові люди [35]. За даними Міжнародної федерації діабету, кількість хворих з Цд зросте з 425 мільйонів у 2017 р. до 629 мільйонів у 2045 р. [36]. Враховуючи наведене, можна припустити, що ХП та ЦД є вагомим фактором ризику розвитку РПЗ.

У ряді сучасних досліджень встановлено, що наявність ЩД породжує ризик розвитку та прогресування різних видів раку. Відомо про кілька біохімічних механізмів, що пояснюють потенційний зв'язок між ЦД та розвитком РПЗ, зокрема, це розвиток аномальних метаболічних, імунологічних та біохімічних змін за наявності ЦД $[37,38]$.

C. Y. Jeon і співавтори, порівнявши результати лікування пацієнтів з нещодавно виявленим џд та пацієнтів, у яких тривалість хвороби перевищувала три роки, встановили, що довготривалий ЦД призводив до збільшення на 42\% смертності у хворих з резектабельною аденокарциномою ПЗ [39].

S. T. Chari і співавтори спостерігали початок прогресування Цд приблизно за 36 міс до діагностування РПЗ. Тому наявна гіперглікемія може бути дієвим та доступним біомаркером для скринінгу пацієнтів групи ризику [40].

Після оперативних втручань на ПЗ з приводу РПЗ досить часто ЦД стає субкомпенсованим. Як відомо, розвиток ЦД за наявності РПЗ пов’язаний як із руйнуванням $\beta$-клітин, так і з розвитком інсулінорезистентності.

R. Pannala і співавтори на підставі результатів спостереження за групою хворих не лише підтвердили взаємозв'язок між ЦД та РПЗ, а й визначили ЦД як ознаку для потенційно ранньої діагностики РПЗ та рекомендували пацієнтів, які раптово захворіли на ЦД, включати у групу потенційного ризику розвитку РПЗ та проводити щодо них інтенсивний скринінг [41]. До такого ж висновку дійшли R. Dankner і співавтори, які у кожного восьмого хворого з РПЗ виявляли Цд, а вперше виявлений ЦД використовували як підставу для підозри розвитку РПЗ [35].
E пропозиції визначати рівень глікованого гемоглобіну (HbA1c) у хворих з ЦД з метою ранньої діагностики РПЗ. Встановлено, що рівень НbА1c, який більш ніж удвічі перевищує норму, підвищує ризик розвитку РПЗ та на 5 років випереджає появу його клінічних симптомів [42].

РПЗ не має специфічних симптомів. Нещодавно А. Каnno і співавтори [14] опублікували звіт про особливості РПЗ, виявленого на ранній стадії. Лише 25\% хворих мали симптоми, найчастішим серед яких був біль у животі - 72\% всіх спостережень, біль у спині, нудота, діарея та жовтяниця - відповідно 26,0, 8,0, 2,0 та 2,0\% спостережень. Часто відмічають прогресивну втрату маси тіла аж до анорексіі.

В епоху найвищого розвитку медицини, незважаючи на широку доступність складних діагностичних методів, у понад 30\% хворих хірург не може передопераційно встановити, чи патологічний процес у ПЗ є запально-дегенеративним, чи злоякісним [43]. Доступні візуальні методи досліджень відіграють ключову роль у характеристиці вогнищевих уражень ПЗ, встановленні стадії захворювання, хірургічному та терапевтичному плануванні. УЗД, як правило, це стартовий метод інструментальної діагностики у пацієнтів, які скаржаться на біль у животі та наявність жовтяниці.

Найбільшу інформативність має ендоскопічне УЗД, яке нівелює ультразвукові перешкоди шлунка та дванадцятипалої кишки, уможливлює виявлення малих панкреатичних (до 10 мм) та періампулярних пухлин, а також гістологічне підтвердження діагнозу шляхом виконання тонкоголкової аспіраційної біопсії [44].

Серед суміжних методів мультидетекторна комп'ютерна томографія (МдКТ) показала найкращі результати для оцінки уражень судин, що є найважливішим фактором для прогнозування резектабельності пухлини. 3 точки зору моніторингу лікувального ефекту хіміотерапії або хірургічного втручання МДКТ є основним методом візуалізації. Втім, за допомогою МДКТ не можна виявити невеликі метастази в печінці або очеревині, навіть первинну пухлину ПЗ. Хоча МДКТ у даний час відіграє важливу роль в оцінці РПЗ, за допомогою магнітно-резонансної томографії (МРТ) та магнітно-резонансної холангіопанкреатографіі (МРХПГ) більш успішно виявляють пухлини на ранній стадії, що забезпечує всеосяжний аналіз морфологічних змін у паренхімі залози, а також у ії протоках.

Позитронно-емісійна томографія з 18F - фтордезоксиглюкозою (18F - ФДГПЕТ) більш чутлива до моніторингу лікувального ефекту хіміотерапії і для виявлення рецидиву пухлини після резекції, ніж МДКТ, проте властиві їй низька роздільна здатність, помилково-позитивні результати, обумовлені нормальним фізіологічним розподілом ФДГ, лімітують рутинне використання методу.

Традиційно гіперсекрецію протеїнів/епітопів, таких як СА 19-9, CA 50, PEA, DUPAN2, а також багатьох інших сполук використовують для діагностики як маркери РПЗ. Найбільш дослідженим маркером РПЗ є СА 19-9, який секретують клітини ПЗ у разі іі ураження. S. Perumal і співавтори [45] повідомили, що СА 19-9 був найважливішим фактором у прогнозуванні розвитку раку ПЗ у хворих з ХП, а його рівень вище 127 МО/мл мав чутливість 85,7\% і специфічність 96,5\%. У літературі є повідомлення про те, що рівень СА 19-9 понад 300 МО/мл мав специфічність 100\% для прогнозування злоякісності. Проте рівень СА 19-9 не є специфічним маркером виключно для РПЗ і тому його не можна вважати скринінговим 
для цієї пухлини. Доведено, що деякі інші стани, включаючи гепатобіліарні захворювання (помилково-позитивний результат за наявності обтураційної жовтяниці), захворювання ПЗ і злоякісні пухлини шлунка та кишечника, застійну серцеву недостатність, муковісцидоз, дивертикуліт, рак легенів, кісти яєчників і нирок, ревматоїдний артрит, можуть супроводжуватись підвищенням рівня СА 19-9. А.В. Клименко вважає, що підвищення рівня онкомаркера СА 19-9 у хворих з ХП менш ніж у 5 разів не може бути диференційно-діагностичним критерієм наявності онкопроцесу в ПЗ [46]. У 2017 p. J. Kim i співавтори запропонували новий маркер- білок тромбоспондин - 2 (THBS2) та підтвердили його ефективність у комбінації із СА 19-9 для кращої ранньої діагностики РПЗ, оскільки СА 19-9 є достовірним за наявності пухлини розміром 2 - 3 см, що інколи позбавляе можливості виконати радикальне оперативне втручання [47].

Якщо концентрація СА 19-9, визначена до проведення неоад’ювантної або ад’ювантною хіміотерапії, знижується після його закінчення, це прогнозує тривалішу виживаність.

Новітні дослідження, крім біомаркерів РПЗ, також стосуються циркулюючих мікроРНК, які вивільняються раковими клітинами у значних кількостях. Серед ціеї групи РНК найбільш вивченими для діагностики РП 3 є miR-21 та miR-155. У 79\% хворих з РП3, які мали високий титр miR-21 та miR155, перебіг захворювання був найгірший. J. Y. Park і співавтори дослідили, що пригнічення експресії miR-21 та miR-155 затримувало клітинний цикл у пресинтетичній фазі (G1) та викликало індукцію апоптозу, а також корелювало з пролонгацією життя та значно підвищувало ефект хіміотерапії [48].

Виходячи з даного огляду літератури, можна зробити чіткий висновок, що ХП та ЦД мають значний вплив на розвиток РПЗ. Крім вказаних, сотні не менш важливих механізмів сприяють злоякісній трансформації, що підтверджується новими дослідженнями.

Слід розуміти, що Цд, ГП або ХП, куріння, зловживання алкоголем, високий індекс маси тіла, PanIN, IPMN та наявний сімейний панкреатит - це провісники можливого розвитку раку, які допоможуть діагностувати дану патологію на ранніх стадіях, виконати радикальне оперативне втручання, максимально подовжити життя пацієнта та покращити його якість. Вважаємо, що необхідно більш активно впроваджувати агресивну та радикальну оперативну тактику за наявності ускладнених форм ХП та різного роду супутніх ускладнень, пов'язаних з гепатопанкреатобіліарною системою. Щодо пацієнтів, раніше оперованих з приводу ХП, має бути проведний інтенсивний післяопераційний скринінг для вчасного попередження маніфестації ХП та можливого його прогресування аж до розвитку РПЗ.

Для більш точної верифікації діагнозу необхідно виконувати інтраопераційну масивну біопсію під контролем ендоскопічного УЗД та розглядати можливість розширеного резекційного оперативного втручання у хворих з високим ризиком розвитку РПЗ аж до виконання субтотальної та тотальної панкреатектомії.

\section{Підтвердження}

Фінансування. Джерело фінансування наукової роботи - кошти авторів.

Інформація про внесок кожного учасника. Внесок кожного автора в цю роботу однаковий. Всі автори прочитали і схвалили остаточний варіант рукопису.
Конфлікт інтересів. Автори, які взяли участь в цьому дослідженні, декларують відсутність конфлікту інтересів щодо цього рукопису.

Згода на публікацію. Всі автори дали згоду на публікацію цього рукопису.

\section{References}

1. Maisonneuve P, Lowenfels AB. Risk factors for pancreatic cancer: a summary review of meta-analytical studies. Int J Epidemiol. 2015 Feb;44(1):18698. doi: $10.1093 /$ ije/dyu240.

2. Hao L, Zeng XP, Xin L, Wang D, Pan J, Bi YW, et al. Incidence of and risk factors for pancreatic cancer in chronic pancreatitis: A cohort of 1656 patients. Dig Liver Dis. 2017 Nov;49(11):1249-56. doi: 10.1016/j.dld.2017.07.001.

3. Hezel AF, Kimmelman AC, Stanger BZ, Bardeesy N, Depinho R.A. Genetics and biology of pancreatic ductal adenocarcinoma. Genes and Development. 2006 May 15;20(10):1218-49. doi: 10.1101/gad.1415606.

4. Rooman I, Real FX. Pancreatic ductal adenocarcinoma and acinar cells: a matter of differentiation and development? Gut. 2012 Mar;61(3):449-58. doi: 10.1136/gut.2010.235804.

5. Sandgren EP, Quaife CJ, Paulovich AG, Palmiter RD, Brinster RL. Pancreatic tumor pathogenesis reflects the causative genetic lesion. Proceedings of the National Academy of Sciences of the United States of America. 1991 Jan 1;88(1):93-7. PMID: 1986386.

6. Kirkegaard J, Mortensen FV, Cronin-Fenton D. Chronic Pancreatitis and Pancreatic Cancer Risk: A Systematic Review and Meta-analysis. Am J Gastroenterol. 2017 Sep;112(9):1366-72. doi: 10.1038/ajg.2017.218.

7. Warshaw AL, Fernandez-Del Castillo C. Pancreatic carcinoma. N Engl J Med. 1992 Feb 13;326(7):455-65. doi: 10.1056/nejm199202133260706.

8. Ferlay J, Soerjomataram I, Ervik M, Dikshit R, Eser S, et al. Cancer incidence and mortality worldwide: sources, methods and major patterns in GLOBOCAN 2012. Int J Cancer. 2015 Mar 1;136(5):359-86. doi: 10.1002/ijc.29210.

9. Bray F, Ferlay J, Soerjomataram I, Siegel RL, Torre LA, Jemal A. Global Cancer Statistics 2018: GLOBOCAN estimates of incidence and mortality worldwide for 36 cancers in 185 countries. CA Cancer J Clin. 2018 Nov;68(6):394-424. doi: 10.3322/caac.21492.

10. Muniraj T, Jamidar PA, Aslanian HR. Pancreatic cancer: a comprehensive review and update. Dis Mon. 2013 Nov;59(11):368-402. doi: 10.1016/j. disamonth.2013.08.001.

11. Ilic M, Ilic I. Epidemiology of pancreatic cancer. World J Gastroenterol. 2016 Nov 28;22(44): 9694-705. doi:10.3748/wjg.v22.i44.9694.

12. Kopchak V, Homyak I, Kopchak K, Duvalko A, Pererva L, Simonov O, et al. Radical surgical treatment of malignant periampullar neoplasms. Klinicheskaya onkologia. 2011;(1):36-9. [In Russian].

13. Kikuyama M, Kamisawa T, Kuruma S, Chiba K, Kawaguchi S, Terada S, et al. Early Diagnosis to Improve the Poor Prognosis of Pancreatic Cancer. Cancers. 2018 Feb 11;10(2):48. doi:10.3390/cancers10020048.

14. Kanno A, Masamune A, Hanada K, Maguchi H, Shimizu Y, Ueki T, et al. Multicenter study of early pancreatic cancer in Japan. Pancreatology. 2018 Jan;18(1):61-7. doi: 10.1016/j.pan.2017.11.007.

15. Yokode M, Akita M, Fujikura K, Kim MJ, Morinaga Y, Yoshikawa S, et al. High-grade PanIN presenting with localized stricture of the main pancreatic duct: A clinicopathological and molecular study of 10 cases suggests a clue for the early detection of pancreatic cancer. Histopathology. 2018 Aug;73(2):247-58. doi: 10.1111/his.13629.

16. Fernandez E, La Vecchia C, Porta M, Negri E, d'Avanzo B, Boyle P. Pancreatitis and the risk of pancreatic cancer. Pancreas. 1995 Aug;11(2):1859. PMID: 7479677.

17. Lowenfels, AB, Maisonneuve P, Cavallini G, Ammann RW, Lankisch PG, Andersen JR, et al. Pancreatitis and the risk of pancreatic cancer. International Pancreatitis Study Group. N Engl J Med. 1993 May 20;328(20):14337. doi: 10.1007/s10552-009-9424-X.

18. Sukhodolia A, Pidmurnyak O, Sukhodolia S, Troparchuk O, Kolomiets O. Diagnostics and Identification of surgical treatment tactics of complicated forms of chronic pancreatitis. Shpytalna khirurhiia. 2016;(3):53-6. [In Ukrainian].

19. Virchow R. The Cellular Pathology. 4th ed. Berlin: Hirschwald; 1871.582 p.

20. Greer JB, Whitcomb DC. Inflammation and pancreatic cancer: an evidencebased review. Curr Opin Pharmacol. 2009 Aug;9(4):411-8. doi: 10.1016/j. coph.2009.06.011.

21. Karanjia ND, Singh SM, Widdison AL, Lutrin FJ, Reber HA. Pancreatic ductal and interstitial pressure in cats with chronic pancreatitis. Dig Dis Sci. 1992 Feb;37(2):268-73. PMID: 1735346. 
22. Whatcott CJ, Diep CH, Jiang P, Watanabe A, LoBello J, Sima C, et al. Desmoplasia in Primary Tumors and Metastatic Lesions of Pancreatic Cancer Clin Cancer Res. 2015 Aug 1;21(15):3561-8. doi: 10.1158/1078-0432. CCR-14-1051.

23. Kirkegaard J, Mortensen FV, Cronin-Fenton D. Chronic Pancreatitis and Pancreatic Cancer Risk: A Systematic Review and Meta-analysis. Am J Gastroenterol. 2017 Sep;112(9):1366-72. doi: 10.1038/ajg.2017.218.

24. Rijkers AP, Bakker OJ, Ahmed Ali U, Hagenaars JCJP, van Santvoort HC, Besselink MG, et al. Risk of Pancreatic Cancer After a Primary Episode of Acute Pancreatitis. Pancreas. 2017 Sep;46(8):1018-22. doi: 10.1097/ MPA.0000000000000879.

25. Javier Martinez-Useros, Weiyao Li, Marticela Cabeza-Morales, Jesus Garcia-Foncillas. Oxidative Stress: A New Target for Pancreatic Cancer Prognosis and Treatment. J Clin Med. 2017 Mar; 6(3):29. doi:10.3390/jcm6030029.

26. Yu JH, Kim H. Oxidative stress and cytokines in the pathogenesis of pancreatic cancer. J Cancer Prev. 2014 Jun;19(2):97-102. doi: 10.15430/ JCP.2014.19.2.97.

27. Dronov OI, Kryuchyna YeA, Khomenko DI, Skomarovsky OA, Gorlach AI, Zemskov SV, et al. Chronic pancreatitis as a risk factor of pancreatic cancer development. Khirurhiia Ukrainy. 2013 Sept; 47(3):112-6.[In Russian].

28. Okami J, Yamamoto H, Fujiwara Y, Tsujie M, Kondo M, Noura S, et al. Overexpression of cyclooxygenase-2 in carcinoma of the pancreas. Monden M Clin Cancer Res. 1999 Aug;5(8):2018-24. PMID: 10473081.

29. Almoguera C, Shibata D, Forrester K, Martin J, Arnheim N, Perucho M. Most human carcinomas of the exocrine pancreas contain mutant $\mathrm{c}-\mathrm{K}$-ras genes. Cell. 1988 May 20;53(4):549-54. PMID: 2453289.

30. Pellegata NS, Sessa F, Renault B, Bonato M, Leone BE, Solcia E, et al. $\mathrm{K}$-ras and p53 gene mutations in pancreatic cancer: ductal and nonductal tumors progress through different genetic lesions. Cancer Res. $1994 \mathrm{Mar}$ 15;54(6):1556-60. PMID: 8137263.

31. Bryant KL, Mancias JD, Kimmelman AC, Der CJ. KRAS: Feeding pancreatic cancer proliferation. Trends Biochem Sci. 2014 Feb;39(2):91-100. doi: 10.1016/j.tibs.2013.12.004.

32. Lohr M1, Kloppel G, Maisonneuve P, Lowenfels AB, Luttges J. Frequency of K-ras mutations in pancreatic intraductal neoplasias associated with pancreatic ductal adenocarcinoma and chronic pancreatitis: a meta-analysis. Neoplasia. 2005 Jan;7(1):17-23. doi: 10.1593/neo.04445.

33. Wang X, Wang J, Chen F, Zhong Z, Qi L. Detection of K-ras gene mutations in feces by magnetic nanoprobe in patients with pancreatic cancer: A preliminary study. Exp Ther Med. 2018 Jan;15(1):527-31. doi: 10.3892/ etm.2017.5368

34. Sarkar FH, Banerjee S, Li Y. Pancreatic cancer: pathogenesis, prevention and treatment. Toxicol Appl Pharmacol. 2007 Nov 1;224(3):326-36. doi: 10.1016/j.taap.2006.11.007

35. Dankner R, Freedman LS, Gerstein H, Roth J, Keinan-Boker L. Newly diagnosed type 2 diabetes may serve as a potential marker for pancreatic cancer. Diabetes/Metabolism Research and Reviews. 2018 Sept;34(6). doi: $10.1002 /$ dmrr.3018.

36. IDF diabetes atlas - eight edition [Internet]. 2017. Available from: https:// www.idf.org/e-library/epidemiology-research/diabetes-atlas/134-idf-diabetes-atlas-8th-edition.html
37. Heidemann C, Boeing H, Pischon T, Nothlings U, Joost HG, Schulze MB, et al. Association of a diabetes risk score with risk of myocardial infarction, stroke, specific types of cancer, and mortality: a prospective study in the European Prospective Investigation into Cancer and Nutrition (EPIC)Potsdam cohort. Eur J Epidemiol. 2009;24(6):281-8. doi: 10.1007/s10654 009-9338-7.

38. Permert J, Ihse I, Jorfeldt L, von Schenck H, Arnqvist HJ, Larsson J. Pancreatic cancer is associated with impaired glucose metabolism. Eur J Surg. 1993 Feb;159(2):101-7. PMID: 8098623.

39. Jeon CY, Li D, Cleary S, Stolzenberg-Solomon R, Bosetti C, La Vecchia $\mathrm{C}$, et al. The Association of Recently Diagnosed Diabetes and Long-term Diabetes With Survival in Pancreatic Cancer Patients: A Pooled Analysis Pancreas. 2018 Mar;47(3):314-20. doi: 10.1097/MPA.0000000000000989.

40. Chari ST, Leibson CL, Rabe KG, Timmons LJ, Ransom J, Andrade M, Petersen GM. Pancreatic Cancer-associated Diabetes Mellitus: Prevalence and Temporal Association with Diagnosis of Cancer. Gastroenterology. 2008 Jan;134(1):95-101. doi: 10.1053/j.gastro.2007.10.040.

41. Pannala R, Basu A, Petersen GM, Chari ST. New-onset diabetes: a potential clue to the early diagnosis of pancreatic cancer. Lancet Oncol. 2009 Jan;10(1):88-95. doi: 10.1016/S1470-2045(08)70337-1.

42. Sadr-Azodi O, Gudbjornsdottir S, Ljung R. Pattern of increasing HbA1c levels in patients with diabetes mellitus before clinical detection of pancreatic cancer - a population-based nationwide case-control study. Acta Oncol. 2015 Jul;54(7):986-92. doi: 10.3109/0284186X.2015.1006402.

43. Smith CD, Behrns KE, van Heerden JA, Sarr MG. Radical pancreatoduodenectomy for misdiagnosed pancreatic mass. Br J Surg 1994;81:585-9. PMID: 7911387.

44. Wiersema MJ, Vilmann P, Giovannini M, Chang KJ, Wiersema LM. Endosonography-guided fine-needle aspiration biopsy: diagnostic accuracy and complication assessment. Gastroenterology. 1997 Apr;112(4):108795. PMID: 9097990.

45. Perumal S, Palaniappan R, Pillai SA, Velayutham V, Sathyanesan J. Predictors of malignancy in chronic calcific pancreatitis with head mass. World J Gastrointest Surg. 2013 Apr 27;5(4):97-103. doi: 10.4240/wjgs.v5.i4.97.

46. Klimenko A. Importance of onomarker CA 19-9 in diagnostics of chronic pancreatitis. Zaporozhye Medical Journal. 2013;(1):29-31. doi. org/10.14739/2310-1210.2013.1.15450. [In Ukrainian].

47. Kim J, Bamlet WR, Oberg AL, Chaffee KG, Donahue G, Cao XJ, et al. Detection of early pancreatic ductal adenocarcinoma with thrombospondin-2 and CA19-9 blood markers. Sci Transl Med. 2017 Jul 12;398(9):55-83. doi: 10.1126/scitranslmed.aah5583.

48. Park JY, Helm J, Coppola D, Kim D, Malafa M, Kim SJ. MicroRNAs in pancreatic ductal adenocarcinoma. World J Gastroenterol. $2011 \mathrm{Feb}$ 21;17(7):817-27. doi: 10.3748/wjg.v17.i7.817.

Надійшла 26.12.18 